\title{
The earliest Jesus group in Jerusalem ${ }^{1}$
}

Andries van Aarde

(University of Pretoria)

\section{ABSTRACT}

\section{The earliest Jesus group in Jerusalem}

Church formation in the history of early Christianity emanated from the kerygma about Jesus after his death. The kerygma was based on memories of Jesus which were used in the Christian cult as both explanation and apology for the encountering of God through the traditions about the crucified, buried, resurrected, and ascended Jesus. The aim of the article is to argue that the term "the Twelve" served as a self-reference of the earliest Jesus group in Jerusalem. They regarded themselves as "apostles" and "prophets" of the "new Israel", analogous to the twelve patriarchs in the Hebrew Scriptures. Reconstructing a trail from Jesus to the earliest group in Jerusalem to Paul, the article demonstrates a fundamental difference between Paul and the Jerusalem group. They understood the notion of "the Twelve" as exchangeable for "all of Israel", represented by "all the apostles". For Paul the concept "apostles" is an expansion of "the Twelve" in Jerusalem.

\section{INTRODUCTION}

Despite his centrality in Christian theology Jesus should not be seen as the founder of Christianity. Although his vision, sayings and deeds constitute the foundational narrative of a religion that has become to be known as Christianity, he was not the "founder" of a cult. Early Christian literature used terms such as "pilars" to refer to people who fulfilled this formative role as "founder patrons" (cf Smith 2000:65-66; Martyn 1997:205). Neither are the words

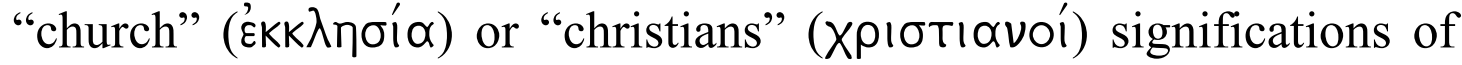
self-expression used by all groups of the earliest Jesus followers in

1 Paper presented at the mini-conference "Continuity - Changes Breaks: Problems of Reconstructing the History of Early Christianity", with Prof Dr Dietrich-Alex Koch from the Neutestamentliches Seminar, Evangelisch-Theologische Fakultät, Westfälische-Wilhelms Universität, Münster, Germany, held at Hammanskraal, University of Pretoria, 25-26 August 2004, organised by the Department of New Testament Studies, Faculty of Theology, University of Pretoria. 
the various locations inside or outside Judea, as can be seen on account of the absence of these words in the earliest stratum ${ }^{2}$ of

2 The earliest Christian texts originated in 30-60 CE. Four authentic Pauline letters $1 \mathrm{Ts}$; Gl; 1 Cor; Rm) form this stratum. Some Jesus sayings in the Gospel of Thomas can also be traced back to this period (see Crossan [1985] 1992:3-19; Patterson 1993a; 1993b:13; Miller 1992:302-303; Riley 1994:234). The second stratum originated in 60-80 CE and consists of several documents: the Gospel of the Egyptians (only known from citations in patristic letters and independent of the canonical gospel tradition - see Koester 1980:238-256; Funk 1985:371), the Secret Gospel of Mark (see Crossan 1992:61-75; Smith 1973; Miller 1992:402-405; Koester \& Patterson 1991:14-16), the Gospel of Mark, Papyrus Oxyrhynchus 840 (see Crossan 1991:430; Cameron 1982:53; Miller 1992:412-415), the "second edited" layer on the Gospel of Thomas (originated probably in Syrian Edessa on account of the alleged authority of Thomas), a collection of dialogues which were embedded in the Dialogue of the Savior, independent from the canonical gospel tradition and editorially finalized in $150 \mathrm{CE}$ - see Pagels \& Koester 1978:66-74; Miller 1992:336-350; Crossan 1991:430; Koester 1980: 255-256), and the deutero-Pauline letter Colossians. Some scholars regard the hypothetical "Signs Gospel", embedded in the Gospel of John, as part of the second stratum (see Fortna 1988 and Von Wahlde 1989). On the level of the third stratum, originated in the latter part of the first and beginning of the second century CE, we find the Gospel of Matthew, Luke-Acts, the Revelation of John, First Clement, the Letter of Barnabas, Didache 1:1-3a and 2:2-16:2 (independent from the canonical gospel tradition and to be distinguished from the later addition, Didache 1:3b-2: 1, an apocalyptic source behind Didache 16:3-5 (see Crossan 1991:431; Draper 1985), the Shepherd of Hermas, Mandate 2:4-7 (see Osiek 1997; Brox 1991:55-71), the Letter of James, the Gospel of John, seven letters by Ignatius, First Peter, the Letter of Polycarp to the Philippians 13-15 (see Koester 1982:306-308), and the First Letter of John. The fourth and final stratum originated in 120$150 \mathrm{CE}$. This stratum consists of the Protevangelium of James (see Cameron 1982:55-570, $1^{\text {st }}$ and $2^{\text {nd }}$ Timothy, Second Peter, the Letter of Polycarp to the Philippians 1-12, Second Clement, the Gospel of the Nazoraeans (23 excerpts from Matthew which is known because of their patristic quotations and margin notes in a "family of manuscripts" taken from the so-called "Zion Gospel" in the $5^{\text {th }}$ century, but of which the translations can probably be traced back to the $2^{\text {nd }}$ century CE (see Koester 1982:201-202; Cameron 1982:97-98), the Gospel of the Ebionites (written circa $150 \mathrm{CE}$ and dependent on a harmonized version of Matthew and Luke, and probably also Mark; all seven excerpts were quoted by Epiphanius at the end of the 4 century; Epiphanius referred to this "gospel" by mistake as the Gospel of the Hebrews - see Koester [1980] 1987:201-202; Davies \& Allison [1997] 2004:725-77); the latter is to be found in Jerome's commentary on Isaiah 4 - 
Christian literature such as the Sayings Gospel Q and the Gospel of Mark. The term "christianoi" (Xpıotıavoí) is an example of stereotyping (Pilch 1997:119-125) used by Judeans and Romans to refer to Jesus followers in, for example, Syria (see Acts 11:26) ${ }^{3}$.

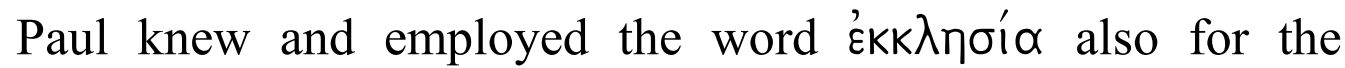
"churches of Judea" (Gl 1:21-22), probably as a distinction of "synagogue" (бuvó $\gamma \omega \gamma \eta)$ (cf Schrage 1963:178-202). This usage reappears in Acts, maybe because of Paul's influence. On the other hand, the occurrence of the term '́KK $\lambda \eta \sigma i \alpha$ in Matthew begs for an explanation. The question is whether this word, in light of Matthew's overall conformation with the "Jerusalem group" (cf Hengel 1995:155, 158, 167, 173, 181), reflects the self-reference of the movement of Jesus followers in Jerusalem. Another question is whether such an organised Jesus movement ever existed in Jerusalem during the immediate years after the crucifixion of Jesus. Some scholars (see Miller 1995:27) are convinced that the existence

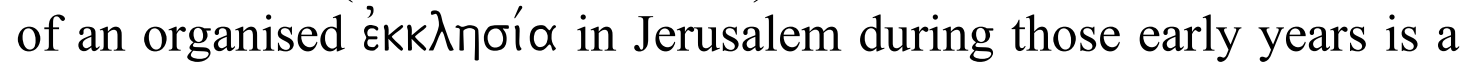
fiction of the author of Acts on account of his interpretation of Paul's controversy with opponents in the letter to the Galatians ${ }^{4}$.

In this article these issues will be addressed from the assumption that what was probably historically first with regard to "church formation", is the kerygma about Jesus. The kerygma was based on collective memories of a historical Jesus which were used in the Christian cult as both explanation and apology for the

see Tatum 1994:89; the original title of the Gospel of the Ebionites is unknown to us - see Koester 1982:202-203; Cameron 1982:103-104), Didache 1:3b-2:1 (a kind of harmonization of Jesus sayings in Matthew, Mark and Luke - see Layton 1968:343-383; Crossan 1991:433), the Gospel of Peter (see Crossan 1998:7-52; Dewey 1998:53-70).

3 The word xpiotiavoí in Acts 11:26 refers to the followers of Jesus who were, according to Acts, called by this term for the first time

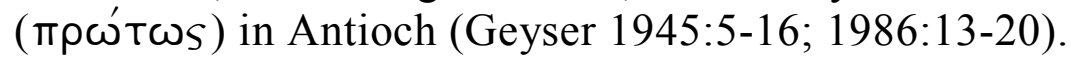

4 Dennis Smith (2000:62) formulates a similar opinion as follows: "I would argue that the Jerusalem 'church' as power broker in Christian origins was a mythological construct from the outset, first appearing among Paul's opponents in Galatia, then picked up and elaborated on by Luke in Acts. The actual ecclesia in Jerusalem, such as it was, most likely played a minor role in Christian origins. But the Jerusalem of myth was utilized to buttress a mythological Jerusalem 'church' in order to gain advantage in the early debates among the Jesus movements". 
encountering of God through the traditions about Jesus who was deified after his death. The aim of the article is to argue that the term "the Twelve" served as a self-reference of the earliest Jesus group in Jerusalem. They regarded themselves as "apostles" and "prophets" of the "new Israel", analogous to the twelve patriarchs in the Hebrew Scriptures. Following a reconstructed trial from Jesus to the earliest group in Jerusalem to Paul, the article demonstrates a fundamental difference between Paul and the Jerusalem group. They understood the notion of "the Twelve" as exchangeable for "all of Israel", represented by "all the apostles". For Paul the concept "apostles" is an expansion of "the Twelve" in Jerusalem.

\section{FROM JESUS TO PAUL VIA JERUSALEM}

Some of the traditions about Jesus (e.g., in the Gospel of Thomas and the Sayings Gospel Q) were soteriologically grounded in their ethical following after Jesus' example and other (e.g., in Paul's writings and in the Gospel of Mark) in their existential participation in the martyr-like death and resurrection of Jesus who became for them the resurrected Christ. This resurrection belief was grounded in apocalypticism. Thus, theologically spoken, what was first was apocalypticism, as Ernst Käsemann ([1960] 1969:102) remarked: "Apocalyptic(ism) $)^{5}$ was the mother of all Christian theology - since we cannot really class the preaching of Jesus as theology." Jesus never conceived the church or intended to establish the church. In other words, neither the concept church nor the kind of apocalypticism of those early Christians who saw themselves as 'KKK $\lambda \eta \sigma^{\prime} \alpha$ were products of Jesus' will, intention, or action. My contention is that both the notions "church" and the

5 With regard to Käsemann's above-mentioned dictum, Murphy (1994:164) formulates as follows: "Since the work of Weiss and Schweitzer, scholars have wrestled with the degree to which apocalypticism influenced Jesus' thought. Käsemann claimed that although the early church was very apocalyptic, Jesus was not (1969). Presently, there is a strong movement stressing non-apocalyptic aspects of Jesus' teaching or of earliest Christian tradition, and seeing apocalyptic elements as later additions by the church .... On the other side are those who reason from such evidence as Jesus' association with John the Baptist, whose preaching is considered eschatological, and the apocalyptic nature of much of the early church, that it is likely that Jesus himself was influenced by apocalypticism" (my emphasis). 
"apocalypticism" attached to it go back to the "theology" of the "founders of the Christian cult" in Jerusalem (see Van Aarde 2001).

The heart of apocalypticism, according to the Israelite mindset, is God who sits on the heavenly throne, with the eschatological son of man at God's right hand. A parallel tradition is that the son of $\mathrm{man} / \mathrm{messiah}$ as representative and saviour of the true people of God is given the authority to judge (cf the Similitudes of 1 Enoch and Mt 25:31ff). According to Hengel (1995:173), "in particular the motif of sessio ad dexteram was material common to early Christian congregations, whether in Corinth, Antioch or Rome, and in my opinion demonstrates incontestably that they go back to the Jerusalem congregation." Although it seems that this earliest Jesus group in Jerusalem considered Jesus as the founder of their movement, it does not mean that Jesus himself fulfilled this role in a historical sense. It was the dynamics of the kerygma of the postEaster Jesus movement that functioned as this foundational originator.

The earliest Jesus apocalyptic movement in Jerusalem emanated from a faith that Jerusalem as "holy city" is the burial place of the "founder" of the Christian cult and the leaders of the group as legitimated to be the founder's "ambassadors", i. e. "apostles", on account of his resurrection appearances to them. In an apocalyptic sense they proclaimed Jesus as martyr in terms of the formula buried, resurrected, and ascended. However, the historical Jesus probably did not regard himself as a kind of apocalyptic martyr, someone with his eyes set on God's future rather on people's presence. This does not mean that he did not have an eschatological vision of how God is to intervene to bring corrupted transience to an end. Futuristically oriented apocalypticism pertained to a vision that God is just. God's judgement was no longer only expected, but was something that is given and will be disclosed at the parousia. It is already a given to all who are waiting in obedience for the final moment of the parousia, to those who hear and accept the prophetic pronouncements of the last judgement.

However, it is an open question whether the "church" in Jerusalem reflects a continuity or discontinuity with the message of 
the historical Jesus ${ }^{6}$. The peculiar quality of Jesus' vision was its inclusivity and antihierarchical tendency. The Jerusalem group is known for its embeddedness in Israel's mores. It is not known for openness towards the nations or for anti-hierarchical inclusivity. Yet it does not mean that there is an absolute discontinuity between Jesus and the earliest Jesus movement in Jerusalem. The historical Jesus brought his message within the scope of Israel. The Jerusalem group searched Scriptures and found evidence that Jesus was adopted by

6 Traditionally, in historical Jesus research, criteria have been used to distinguish between the words and deeds of the historical Jesus and those of his post-Easter followers pretended to have been Jesus' words and deeds. In the early stages of the research, sayings of Jesus reflecting an Israelite environment were distinguished from a later Hellenistic development (see, among others, Hahn 1974:11). Jesus sayings that reflect the convictions of the Jesus movement in the Israelite, as well as in the Greco-Roman environment, have not been regarded as authentic Jesus sayings. This criterion of dissimilarity was applied in such a way that probable authentic Jesus traditions were distinguished from, on the one hand, post-Easter Jesus movements, and on the other hand, from the conventional Israelite tradition. In the case of the Greco-Roman and the Galilean-Syrian contexts, a change in environment caused a discontinuity in the content of words with regard to the transmission of the Jesus tradition, although a material relationship ("sachliche Relation" - see Bultmann [1928] 1969:230) with Jesus still existed. The term "dissimilarity", therefore, does not cover both aspects, continuity and the discontinuity, in the transmission of the Jesus tradition. In view of this shortcoming, Theissen and Winter (1997) refined the issue of "dissimilarity" between Jesus and the Israelite tradition. They replaced the "criterion of dissimilarity" with the "criterion of historical plausibility". By so doing, they pointed out that Jesus was both in continuity and in discontinuity with the Israelite tradition of his day. This kind of approach creates the possibility of describing and explaining the vision of Jesus within the context of the Israelite tradition of his time. Theissen uses the terms "Jesus' Jewish world" (i.e. the Israelite tradition) and "Judaism" (i.e. conventional Judean legalism). This distinction opens up the possibility of applying what I call the "environmental criterion". This criterion can assist in identifying the similarities and differences, the continuity and discontinuity between the words and deeds of Jesus and the interpretation of the evangelists. In this regard, insights into the domestic, social, political, economic, agricultural, urban and religious structures of both the environments of Jesus and those of the early Christian writers will assist in distinguishing the words and deeds of Jesus from the interpretations of Jesus by this followers. 
God to be Israel's messiah (cf Hübner 1981:217-240; Gnilka 1993:201-202, 266-267).

From this messianic outlook and with an apocalyptic mind-set, the Jerusalem group apparently started a process of institutionalizing Jesus' last meal with close followers as a table fellowship symbolizing their participation in God's "spiritual kingdom". These followers of Jesus distinguished themselves from the circle of the disciples of John the Baptist. Like Jesus himself, some of them could initially have belonged to this circle. Their separation was symbolized by their distinctive understanding of the baptismal rite. The baptism by John the Baptist was a water ritual that initiated a lifestyle to be lived when and where God reigns. The fellows of the Jesus movement in Jerusalem institutionalized a "spiritual baptism" in the name of the Father, and the Son, and the Spirit of God as sign of initiation into a discipleship of the "heavenly kingdom". According to their scrutinizing exegesis of the Hebrew Scriptures, this "imperial rule" was inaugurated by Jesus as Israel's spirit-filled messiah who triumphed by his victory over death as it was expected within an apocalyptic mind-set that the Son of Man would do. Apocalypticism can therefore be seen as the mother of the Jerusalem group's theology (Käsemann 1960:180) ${ }^{7}$ and unthinkable without the belief in the resurrection from the death.

The words Jesus never conceived the church or intended to establish the church is a paraphrase of the well-known words of Wolfgang Trilling (1978:68), based upon the remark by Alfred Loisy (in Gnilka 1993:202): "Jesus habe das Reich Gottes verkündet, gekommen sei die Kirche." These words have since been repeated with approval by many historians, of who Geza Vermes (1993:214-215) and Joachim Gnilka (1993:329) are recent examples. The establishment of the "church" is, therefore, not to be traced back

7 "Die Apokalyptik ist - da man die Predigt Jesu nicht eigentlich als Theologie bezeichen kann - die Mutter aller christlichen Theologie gewesen" (Käsemann 1960:180). However, Käsemann's expression "all Christian theology" should be reduced to only the theology of the Jesus group in Jerusalem. Other "Christian" factions, contemporaneous to that in Jerusalem (e.g., the communities respectively responsible for the formative stratum of the Sayings Gospel Q and the first layer of the Gospel of Thomas), did not interpret the Jesus event from an apocalyptic perspective but from a sapiental one. 
to a foundational event in the life of the historical Jesus. After his execution Jesus lived forth through the retelling of his cause. This process resulted in a development of Jesus movements (see Schillebeeckx 1974:38; Schille 1994:104) that reached back to his followers' experience of resurrection appearances of Jesus, in particular, by Mary Magdalene, Peter, James, and Paul (Lüdemann [1994] 1994:68, 100, 170, 176-177, with regard to Peter and Paul, and with regard to Mary Magdalene, contra Lüdemann 1994:160).

For some in early Christianity, it was as if they experienced the appearance of the resurrected Jesus in the form of the Son of Man (for evidence in Matthew, see inter alia Mt 24:30; 27:52-53; 28:1620). The Son of Man is that triumphant apocalyptic figure who had been expected to come at that point in history when the experiences in this world would be almost unendurable so that God's people began to "fantasize" about the inauguration of the Kingdom of God transcending the worrisome times that they experienced (see inter alia Dn 7:13-14). Others could only hold on to the kerygma of those who said that they had been sent by the exalted Jesus to convey his vision (cf Jn 20:29). Paul said explicitly that he was sent by God to become an "apostle for the Gentiles" (see G1 2:8). It is reported that this commission was given to Paul when he was transformed by an epiphany by means of a divine light in which the risen Jesus appeared. This is, however, not described as a visual experience. It is reported that he heard Jesus' voice (see Acts 9:3-4; 22:6-7; 26:1314; cf G1 1:25-27).

Mary of Magdala claimed to have been the first to have experienced an appearance of the risen Jesus. This is probably authentic (see Mk 16:1, 9; Mt 28:1; Lk 24:10; Jn 20:1; Gospel of Peter 12:50; Epistula Apostolorum 9 [in both the Ethiopic and Coptic versions]). Only the Epistula Apostolorum does not place the previously demon-possessed Mary Magdalene first on the list of the women who said they had a vision of the resurrected Jesus. This

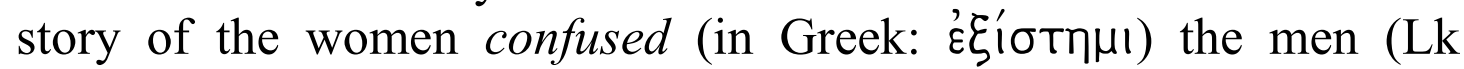
24:22-24) $)^{9}$ - what man could believe the witness of a woman!

8 See Van Aarde (2001), "Matthew and apocalypticism as the "mother of Christian theology": Ernst Käsemann revisited".

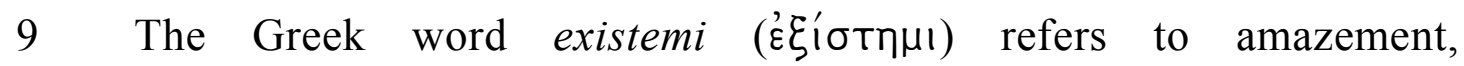
astonishment. 
Fortunately, for the sake of the men, another "stone" pillar of faith confirmed that the master appeared to him (cf Lk 24:34). It seems that Paul believed Peter in that he was actually the first to have seen Jesus $^{10}$, although Peter himself and the other "pillars of faith" fled during the turmoil surrounding Jesus' crucifixion (Mk 14:50). The rumor follows that when Peter's shame prompted him to return his heart failed him again (see Mk 14:34, 66-72). Nevertheless, it is believed that God made him an "apostle for the Israelites" (see Gl 2:8).

According to Paul, Jesus also appeared to the core group of Jesus' followers, believed to be twelve, as if they could claim to represent all the sons of Israel (cf 1 Cor 15:5; Lk 24:36-49; Jn 20:1923; 26-29). Another early tradition was also transmitted, evidenced in Acts 2, that the vision of Jesus began to find its way through the Roman Empire after the "end-time" Spirit of God came upon a larger group of people, from many different ethnic backgrounds, who came to Jerusalem as the prophets said the nations would do. This spiritual experience happened when Peter started "evangelizing," telling the people about the crucified Jesus whom God made to be Lord (Kyrios) and Messiah (Christ) of all of Israel (Israelites and Gentiles included) (cf Acts 2:1-42). Through his death, a transformation of the temple cult took place. Instead of sacrificial rites for receiving forgiveness of sin, everyone could now be baptized in the name of Jesus Messiah as a sign of their spiritual renewal (cf Acts 2:38ff) ${ }^{11}$.

This spiritual vision was caused by the Spirit of God who came upon not only an individual but upon many sons and daughters of Israel (see Acts 2:17-21). According to an earlier transmission of probably the same story, it might have been that their numbers were more than five hundred (see 1 Cor 15:6). Paul, the source of this early testimony ( 1 Cor 15:6), said he was informed that Jesus'

10 Elizabeth Schüssler Fiorenza (1994:12) refers to 1 Cor 15:3-8 as a "list intended to legitimate male authority".

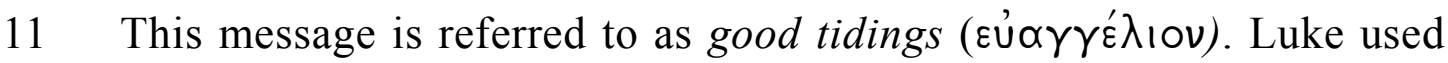
the word gospel over the alleged "good news" of the divine birth of the emperor Augustus who claimed to be the saving patron of the whole world. 
brother James claimed to have seen him after his crucifixion (also witnessed to in the Gospel of the Hebrews, fragment 7, preserved by Hieronymus, De Viris Illustribus 2). This reportedly happened before the appearance to "the Twelve" as a group.

The authority of James' upcoming leadership of the Jesus movement in Jerusalem probably depended on his being a primary witness (see 1 Cor 15:6). Josephus (Ant 20.197-203) mentioned that James became an important official in the priestly circles of Jerusalem after the Romans had killed his brother. The experience of seeing his crucified brother resurrected apparently ignited in James the desire to become a follower of Jesus. However, while Jesus was among them, James, his mother, and other kin from Nazareth did not believe in Jesus' cause. Nevertheless, he became one of the "pillars of faith" in Jerusalem. Having never been a follower of Jesus during his lifetime, it comes as no surprise that James did not believe that the gospel should go further, from Jerusalem through Samaria into the rest of the Roman Empire, even to the world of the barbarians who could not speak Greek.

Another man, Paul, who apparently did not even know Jesus personally, considered himself to be truly an apostle because he advocated this cause ${ }^{12}$. Paul considered his right to be an apostle to be based on the authority of a revelation of the resurrected Jesus (see Gl 1:12 $)^{13}$. Yet Paul dissociated himself from the Jerusalem group with his critique of the idea that the obedience to cultural conventions makes right the relationship with God (see, inter alia, Phlp 3:7-11). He also disagreed with the notion of an apostle bringing the light of the gospel to the nations outside of Jerusalem.

Paul was eventually killed in Rome, so it seems to (despite 1 Clem 5:7), because the Roman emperor Nero used Christians for his own end ${ }^{14}$. Two years earlier, Jesus' brother was also killed in

12 This he did in the midst of afflictions that made him feel like a woman being crucified (according to a "reading between the lines" of 2 Cor 4:12).

13 Here it seems that both parties (the "pillars" in Jerusalem and Paul) used the resurrection belief in a way that indicates that they did not internalize Jesus' disdain for selfish superiority (cf Mk 10:42-44).

14 The emperor wanted to expand the mansions of his family members. For that he needed the land where catacombs were used as shelter by outcasts. He started a fire, lied, and said that Christians were responsible. 
Jerusalem. Josephus (Ant 20:197-203) reported that the high priest eliminated this "pillar of faith" in 62 CE because he and other Pharisees were charged with lawlessness (ávouía), probably because their opposition to the high priest could topple him from his lofty position.

Apart from those pre-Easter followers of Jesus, centered in Jerusalem after his crucifixion, the vision of Jesus soon also created a movement for others - Israelites in the Diaspora and devoted Hellenists who associated themselves with the religion of the "children of Abraham." Pioneers like Paul played a major role in this Jesus movement. The origins of the Jesus movement in Jerusalem seemingly lie in the claims of Peter and James (and probably also the sons of Zebedee, John, and James) that they saw the resurrected Jesus. Mary Magdalene's experience of Jesus' resurrection was not brought up in the tradition of the Jerusalem group. Paul and Mark (and Christian writers dependent on them) knew of this tradition about "the Twelve" and conveyed it further - albeit not very enthusiastically. However, Paul seems unaware of the bias that caused the astonishment among the Jerusalemites about Mary's experience of the resurrected Jesus.

Paul developed a theological construct of participation in the risen Christ Jesus. This "unity" with the cause of Jesus was a faith experience which was expressed by Paul with the formulae "to be in Christ," "to be in the Kyrios," "to be in the Spirit", and "to call upon God as $A b b a$ ". The "live in Spirit" formed an alternative to a life according to everyday cultural arrangements. In this regard, Paul differed from the Jerusalem group in his opinion that the continuing experience of the meaning of Jesus' life through the resurrection belief meant that the "old" Israel died as well.

The Jesus movement in Jerusalem believed that Jesus "restored" Israel as an ethnic entity. For Paul, "the Israel of God" was totally transformed into a spiritual entity. He grounded his conviction in his understanding of Jesus' death and resurrection. The church as a "spiritual" Israel meant that it was seen as a movement of people who believed in Christ and in the Kyrios, the Jesus of faith for both Israelites and non-Israelites ${ }^{7}$. The historical Jesus did not

The outcome of this was that many Christians were killed (cf Tacitus Ann xv.44). 
foresee that an entity like "the church" would be built upon such an interpretation of his death. Yet, to deny the foundation of the church in Jesus' vision is to deny the historic cradle of the church and to allow the essence of the church to evaporate into an ecclesiological ideology. This also amounts to Paul's thinking. He understood that this vision was folly to the world, but wisdom in the eyes of faith (1 Cor 1:18).

The source behind Paul's kerygma is found in the emphasis of Jesus' death by "the Twelve" in Jerusalem (1 Cor 11:23-24; 15:1-5). This does not mean that it was Jesus who established the church or Christianity for that matter. Yet, Paul's anti-hierarchical vision and cultural subversiveness by means of his Torah critique was in continuity with Jesus' relationship with God as the Father of "deklassierten Personen" $"$. For Paul, the essence of religion is doing

15 Rudolf Bultmann ([1960] 1965:11) summarises his understanding of the core of Jesus' vision as follows: "Mit einiger Vorsicht also wird man über das Wirken Jesu Folgendes sagen können. Charakteristisch für ihn sind Exorzismen, der Bruch des Sabbatgebotes, die Verletzung von Reinheitsvorschriften, die Polemik gegen die jüdische Gesetzlichkeit, die Gemeinschaft mit deklassierten Personen wie Zöllnern und Dirnen, die Zuneigung zu Frauen und Kindern; auch ist zu erkennen, daß Jesus nicht wie Johannes der Täufer ein Asket war, sondern gerne aß und ein Glas Wein trank. Vielleicht darf man noch hinzufügen, daß er zur Nachfolge aufrief und eine kleine Schar von Anhängern -Männern und Frauen - um sich sammelte." According to Bultmann, this vision ere was fundamentally related ("sachliche Relation") to Paul's kerygma, albeit a discontinuity in words and phrases ("inhaltliche Diskontinität" exsisted. In terms of the Pauline kerygma, "[i]t is clear that Jesus did not present this kind of explicit theological reasoning. But it seems to me equally clear that by it Paul simply explains and clarifies the thought of Jesus by the use of specific historical antitheses. The reasoning is certainly based on the same fundamental motive, which was the foundation of Jesus' polemic: the opposition between legal right and the true will of God. That opposition is the reason for Jesus' polemic; God's will cannot be enshrined in legal enactments which man can discharge, so that he could exhibit his achievements before God and present a claim... What Jesus does not state is that from the beginning it is impossible for the law at any time to confront [humankind] who desires to gain security by his own achievements in any other way than his 'custodian'. But however remote this theological idea may be from Jesus' preaching, that preaching does actually imply it. This can be recognized in the fact that Jesus sees and says the officially religious, the 'righteous', are not willing to listen either to the Baptist's call to 
what fits in with God (Rm 12:1-2). If rejection and death were seen as failure, folly or offense, then Jesus' vision would have failed. But this paradoxical and repugnant perception was what the life of Jesus pertained to be. Faith and ethics are interwoven and it demands selfdenial. The Pauline tradition conveyed this vision. It is a contracultural perspective without escaping reality. It comprises the vision that strength is possible in weakness, wisdom in folly, honor in shame, and life in death. Cultural institutionalization, whether in accordance to the Israelite temple ideology or to the Greco-Roman socio-relgious way of life, always causes people to become accepting of hierarchical hegemony, exclusive hybrid and alienating agony provoked by the powers that be. Because God turns shame into honor, the resurrection faith is, according to Paul, the sign of a new birth, a new start, a new creation ( 2 Cor 5:17; G1 6:15), the birth of the "true Israel," the "Israel of God" (Gl 6:16). According to Jesus' gospel, faith, i.e. an absolute dependence upon God, meaning an alternative vision and life-style, not arrogant egotism, constitutes the self-understanding of human beings who exist in the presence of God.

\section{THE CIRCLE OF THE TWELVE}

The relatedness between Paul's kerygma and the emphasis of Jesus' death by "the Twelve" in Jerusalem could imply a direct connection between Jesus and Christianity. Scholars (see Conzelmann 1988:341) have referred to some evidence in the New Testament that seemingly traces the establishment of the church directly to Jesus himself. However, this evidence is limited, uncertain, and historically unreliable. Three references in this regard deserve to be mentioned. The first consists of the reported words of Jesus to Peter in Matthew 16:17-19: "You are Peter, and on this rock I will build my church." The next is presupposed in the report on the institution of the Eucharist: "The Lord (Kyrios) Jesus...said: 'This is my body..." (1 Cor 11:23-26; Mk 14:22-25). Both references must, however, without doubt be dated later, and are, in addition, historically unreliable (see Conzelmann 1988:341).

The most outstanding New Testament source that has something to say about the establishment of the church is the Pauline

repentance or to his own, while the tax-collectors and harlots, the 'sinners', listen (Mt. 21.32; Lk 7.29)" (Bultmann [1928] 1969:230; emphasis by Bultmann). 
credo in 1 Corinthians 15:3-5b (Conzelmann [1959] 1973:94). According to the credo, Peter (see also Lk 24:34) was the first observer of an appearance by the resurrected Jesus and therefore, viewed historically, was the "founder" of the church. A second aspect of this credo is that the risen Jesus appeared to "the Twelve" ( 1 Cor 15:5b) and also to "all the apostles" (1 Cor 15:7b). It could, with reference to this, be argued that Jesus himself legitimated "the Twelve" and in this way indirectly gave rise to the idea of the church (expressed in "the Twelve" as representatives of God's chosen people) (cf Conzelmann 1988:341-342).

However, on account of the lack of multiple independent witnesses there is no historical evidence that Jesus called "the Twelve" or sent out the "the apostles". These designations seem to be interchangeable for Mark and for those documents that are modeled after Mark. Paul did not see it this way. He regarded the concept "apostles" as an expansion of "the Twelve" in Jerusalem. My contention is that the group of Jesus followers in Jerusalem created the idea of "the Twelve". The circle of "the Twelve" came into being as a result of the traditions concerning the appearances of the resurrected Jesus. The number twelve represented the apocalyptic "true Israel".

Discipleship presupposes that the historical Jesus called someone who then physically followed him. However, the phrases "disciple of Jesus" and "follower of Jesus" have different connotations. Therefore, according to the gospel tradition, people such as Mary, Martha, Bartimaeus, and Zacchaeus were "followers" of Jesus but not "disciples". The question is whether the designation of "the Twelve" in Mark (e g, Mk 6:7) and John (e g, Jn 6:67) should be seen as an "inner circle" (Meier 1997:637) among Jesus' disciples and whether the term "apostle" equates "disciple" and pertains particularly to the circle known as "the Twelve".

Matthew also employed the phrase "the twelve disciples" (Mt $10: 1 ; 11: 1$; possibly 20:17). This phrase seems to be an equivalent for "disciples". If this is the case, "the Twelve" and the "disciples" were, according to Matthew, the same group of people. However, it is important to notice that the term "twelve apostles" also occurs in Matthew (10:2). Luke, based on Mark, took over the Markan designation of "the Twelve" but does not employ the Matthean phrase "the twelve disciples" or "twelve apostles". According to Meier (1997:638), the "use of 'the Twelve' as completely equivalent 
to 'the disciples' does not reflect the earliest strata of Gospel traditions or the historical situation of Jesus' ministry". I fully agree with Meier in this regard. Yet, I do not find evidence that Jesus called an "inner circle" to whom he referred as "the Twelve" (see Van Aarde 1999:795-826). It was not Jesus who was responsible for the concept "the Twelve" or the phenomenon "the apostles".

Both the Markan character with the name "Levi" (see Mk 2:1315) and the Johannine character with the designation the "beloved disciple" (also referred to as "the other disciple" - see Jn 13:23-25; $18: 15,16 ; 19: 26-27 ; 20: 2,3,8 ; 21: 20-23)$ do not occur in the list of "the Twelve" (Mk 3:16-19) (see Van Aarde 1985:45-62). However, according to Mark and John, both were called "disciple". It is remarkable that, at the time when Levi was reportedly called to be Jesus' disciple (Mk 2:15), Mark did not count him among "the Twelve". At this stage in the Markan narrative, the individuals among "the Twelve" mentioned were Peter, Andrew, James, and John. The actual selection and naming of "the Twelve" was recorded for the first time in Mark 3:13-19.

Mark 3:7 makes a clear distinction between Jesus' disciples and the crowds. Mark 3:13 could therefore be interpreted that Jesus summoned "the Twelve" out of a larger group of disciples. This is how Luke understood Mark 3:13: "And [Jesus] called his disciples, and chose from them twelve...." With regard to Jesus' calling of the "rich man" to be a disciple (Mk 10:17-22) one can also argue that a larger group of disciples apart from "the Twelve" existed. The fact that the "rich man" reportedly responded negatively seems to be irrelevant for Mark when he referred to the "rich man" as a potential disciple.

However, in a number of cases Matthew redactionally changed Mark's tendency to equate "the Twelve" with all of the disciples. For example, in the case of Levi, Matthew transformed "the toll collector's" name into "Matthew" - a name that is found in the list of "the Twelve". Actually, in the Matthean narrative, no individual "disciple" appeared who was not named in the list. Whereas Luke (6:12-16) took over the Markan report of the selection and the naming of "the Twelve" (Mk 3:13-19), Matthew did not narrate a story in which Jesus called "the Twelve" out of a larger group of disciples. When Matthew referred to the calling of the "rich man" and his negative response, he characterized him as someone who associated himself with Jesus' opponents (Van Aarde 1994:56-57). 
Meier (1997:638 note 8) concludes: "Perhaps one can say that Matthew presents the circle of the Twelve as de facto coterminous with the circle of the disciples".

The word "apostles" refers to envoys sent by Jesus and it occurs only once in Mark (6:30). The parenthetical phrase (i.e., printed in italics) in Mark 3:14 ("and [Jesus] appointed twelve, whom he also designated apostles, in order to accompany him and to send them out to proclaim....") should not be seen as the best reading (Meye 1968:190). It represents a secondary reading and should be regarded as a harmonization with Luke 6:13. In the Greek manuscript tradition there are various examples of harmonisation of Mark's story of the selection of the Twelve with Mt 10:1-4 and Lk 6:12-16. In Mark 6:30, the word "apostles" is used within the context of messengers who accomplished their missionary itinerary and it could refer to a concept known in Aramaic as schaliach (see Schmithals 1986:737-738).

This figure was a legitimized agent who was sent out with the full authority of the sender. Matthew (10:2) took the reference to the "apostles" over from Mark. The context of Mark 6 represents the typical Markan "sandwich-style" (Best [1983] 1985:11). Between the sending of the Twelve, two by two (Mk 6:7-13), and the return of the apostles (Mk 6:30-32), the narrator intercalculated the report of John the Baptist's decapitation (Mk 6:1-29). A function of this particular narrating technique in Mark (Rhoads \& Mitchie 1982:4749) could be to create for the implied reader a distance between the role of "the Twelve" and the mission of the "apostles". However, this is no mere repetition, for the second part adds precision and clarifies the first part (Rhoads \& Mitchie 1982:47). Both parts comprise a two-step progressive description. The first part is important, yet the emphasis often lies on the second step, which usually contains the more significant element

After his reference to the completion of the mission by the messengers ("apostles"), Mark does not use the word "apostles" any longer. At least one can conclude that when Mark linked "the Twelve" to the concept "apostles," he did it only within the context of mission. But Markan research has also pointed out that the "disciples" in Mark's story were not very enthusiastic to serve people from outside the boundaries of their own homeland. The story of the apostles' return is followed by the "double story" about Jesus giving bread to people. In the first narration of this story (Mk 
6:35-44), the recipients of bread were people from the land of Israel and the disciples took the initiative (cf. Mk 6:35). In the second version (Mk 8:1-10) the recipients were from across the boundaries of the homeland and the disciples were not only hesitant to react on Jesus' initiative but were also unwilling to act as mediators of Jesus' gift of bread to the people. This "double story" is again intercalculated by, among others, the report of the Syro-Phoenician woman (Mk 7:24-30) who received leftover bread intended to be consumed by dogs. A possible interpretation of Mark's narrative point of view in the mission discourse could be to understand the intention of his creation of a distance between "the Twelve" (i.e., the "disciples") and the "apostles" as an illustration that the nature of their "apostolate" was particularistic. This is exactly how Matthew (10:5) interpreted Mark. Yet, in line with his overall narrative point of view, Matthew did not report this particularistic attitude pejoratively.

However, a comparison with Luke clearly points out that Luke did not consider the "apostles" as equivalent to "the Twelve". For Luke, "apostles" were rather the "itinerants" who traveled two-bytwo (seemingly male and female). It is therefore noticeable that Luke did not characterize Paul as an "apostle". In the Lukan mission discourse, the "itinerants" were numbered seventy (or seventy-two, according to other early manuscripts). It is also important to see that Luke expanded the "mission of the disciples" into a journey with Jesus from Galilee to Jerusalem (commencing at $\mathrm{Lk}$ 9:51) and that they travelled through Samaria. Luke also made it clear that the "disciples James and John" (sons of Zebedee) wanted the Samaritans to be struck by an apocalyptic catastrophe similar to Sodom and Gomorrah (Lk 9:51-56). The sons of Zebedee, clearly disapproved of Jesus travelling through Samaria and their hatred towards the Samaritans, was easily evoked by the reported antagonism of these "bastards" against Jesus. Luke (9:57-62) however compared James and John to "would-be followers" of Jesus. The "itinerants", on the other hand, were implicitly described as "apostles". They traveled to "every city and place" where Jesus himself was prepared to go (Lk $10: 1)$. According to the context in Luke, this reference would include Samaria.

In light of our knowledge of Luke's overall conservative transmission of Q traditions, one can assume that Matthew's version represented more of a radical redactional change of the $\mathrm{Q}$ tradition 
than Luke. In the Sayings Gospel Q and in Luke, the itinerant emissaries were distinguished from "The Twelve" in Jerusalem. This can be seen in the designation in the mission discourse of those who were sent out as "others" ('́tépous). Luke described this group as seventy or seventy-two (Lk 10:1). This is a clear distinction between the "mission of the disciples" and the "mission of the seventy/seventy-two". These "itinerants" were depicted against the disciples such as the sons of Zebedee to whom Luke explicitly referred as "disciples" (Lk 10:5), but in Mark (3:16f) as "The Twelve". Thus, both Luke and Mark created a distance between the "itinerants" and the "disciples"/"the Twelve". The opposing ideologies behind this distinction can be read between the lines as that of a particularistic mission and a universal mission.

Matthew did not only equate the "itinerants" with the "twelve disciples" (Mt 10:1), he also referred to them as the "twelve apostles" (Mt 10:2). According to Matthew, they did not travel on the "road to the nations" or visit a "city in Samaria" (Mt 10:5), but rather $(\mu \hat{\alpha} \lambda \lambda \circ \nu)$ proclaimed the "approaching kingdom of heavens" only to the "lost sheep of the house of Israel" (Mt 10:6). The "rich man" is, for Matthew, a potential follower of Jesus who chose to share the ideological perspective of Jesus' opponents (in Matthew represented by the "coalition" of Pharisees, Sadducees, chief priests and the "elders" in Jerusalem). In Matthew the "rich man" is not seen as a disciple. He displays an ambivalence similar to that of the character of the person without a wedding garment (Mt 22:11-13) in the parable of the wedding banquet (see Van Aarde 1994:242). In Matthew disciples of "little faith" are also tempted to collaborate with the enemy. Like the "rich man", Judas (a "disciple" among "the Twelve") and other renegades revealed their preference by using names for Jesus that were constantly used by the antagonists in Matthew's story (see Van Aarde 1994:54-59).

It seems that Matthew conformed to the group of Jesus followers in Jerusalem. Evidence of the existence of such a group can be based on independent multiple witnesses of the role of James (the brother of Jesus) in this group found in the Pauline tradition (G1 1:19; Acts 1:14 [implied]; 15:13 [explicit]) and Josephus (Antiquitates 20.200). Similar witnesses with regard to the killing of James (the brother of John), due to his role in the Jesus group in Jerusalem, occur in Mark 10:38ff (implied) and in Acts 12:1ff (explicit). 
This group was probably formed around a core group (the socalled "inner-circle") which Paul (G1 2:9) referred to as "the pillars" (of which Cephas, i e Peter, and James, i e, the brother of Jesus, and the brothers James and John were the leaders). This group idealised their movement by thinking about it as the "eschatological Israel" and referring to the "first" disciples as "the Twelve". This designation is clearly analogous to "the twelve patriarchs" referred to in the Hebrew Scriptures.

It seems as though Luke (and Mark as the source of Luke) knew that the indication of the "inner circle" as "the Twelve" was not authentic. Therefore, they interpreted "the Twelve" as a selection from a larger group of disciples. We have seen that Matthew differs from Mark and Luke by equating the "disciples" with "the Twelve". Matthew would not use the term "disciple" when referring to potential disciples. He therefore changed the name "Levi" into "Matthew" in order to have all "disciples" explicitly referred to by a name that occurs in the list of "the Twelve". This list was taken over from Mark, but probably originated earlier within the Jerusalem group. Paul was acquainted with a group in Jerusalem called "the Twelve" but he did not mention their names. He only mentions the leaders Peter and James. Paul's reference to "all the apostles" (عit

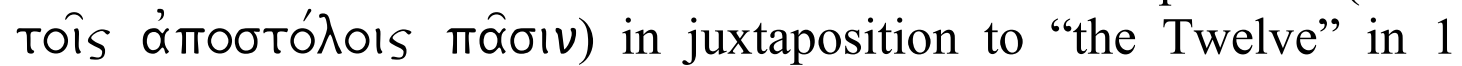
Corinthians 15:3-7 indicates that "apostles" were people who should be seen as an extension of "the Twelve". It means that "the Twelve" were also seen as "apostles", but the "apostles" were not restricted to "the Twelve".

In Luke-Acts "the Twelve" are distinguished from a "crowd of disciples" and also from the "servants of the word" (see Lk 1:2). Probably due to Pauline influence, the election of Matthias in Acts (1:26) is described as an addition to the "eleven apostles" (cf also Acts 2:14). In Acts 6:2 the eleven plus Matthias are called "the Twelve". After Acts 6:2 both the terms "the Twelve" and "apostles" do not appear in Acts again. It seems that the "servants of the word" took over the role of the "apostles" as if they were athletes in a relay race. In Luke 1:2 these two "character roles" are anticipated by means of the expressions "eyewitnesses" and "ministers of the word". It is, however, noticeable that Luke did not describe Matthias as an "apostle". 
It seems that for both Paul and Luke someone could only claim to be an "apostle" if he ${ }^{16}$ was a "witness of Jesus' resurrection" (Acts $1: 22 ; 1$ Cor 15:7f). This is the reason why Paul saw himself as an

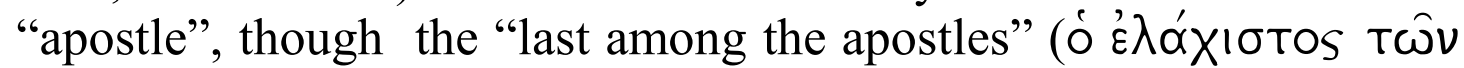

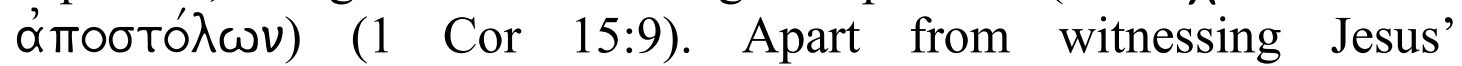
resurrection, Acts (1:22) also expects an apostle to be someone who accompanied Jesus from his baptism to his ascension (see the term "eyewitnesses" in Lk 1:2). In this regard Luke could not have been influenced by the Pauline tradition, since Paul never knew the historical Jesus. This is Lucan Sondergut. It also explains why Luke, apart from Acts 14: 4 and 14, preferred not to call Paul an "apostle" in Acts $^{17}$. However, the New Testament does not attest unanimously that the "apostles" were the same as "the Twelve". We have seen that this is Matthew's presentation. In this regard it could be that Matthew conformed to the Jerusalem group's opinion. The world of Matthew seems to depict a Syrian situation (Antioch?) that reflects Pauline influence, albeit more than forty years after Paul's contact with Antioch. According to Meier (1997:639 note 12) "(t)he viewpoint of the late-first-century church may be reflected ever so fleetingly here". For Mark "apostles" were emissaries who should be distinguished from the Jerusalem group.

16 It seems that Luke (see Lk 24:10f, 22f) and Paul (see the omission in 1 Cor 15:3-8) found it difficult to take the witness of women, such as Mary Magadelene, seriously.

17 Schmithals (1982:131) refers to Paul's "apostleship" in Acts as follows: "In V.4 überrascht wie in V.14 die Bezeichnung 'Apostel' für Paulus und Barnabas. Da Lukas den Aposteltitel im übrigen für die Zwölf Apostel reserviert, um sie wegen ihrer unwiederholbaren Rolle am Beginn der apostolischen Tradition auszuzeichen (vgl. 1,21f.), dürfte im vorliegenden Fall die Bezeichnung 'Apostel' für Paulus und Barnabas auf die Quelle des Lukas zurückgehen. Natürlich hat Lukas diese Bezeichnung nicht ohne Bedacht übernommen (oder ggf. eingeführt). Daß Paulus selbst sich mit Betonung 'Apostel' nannte, war Lukas ohne Frage bekannt. Er konzediert diese Benennung auch, freilich in der hier vorliegenden funktionalen Weise: Paulus ist Apostel nur wie Barnabas in dem allgemeinen Sinn, in dem man die christliche Missionäre, die von Antiochien abgesandt wurden (13, 1-3), 'Apostel' (= Abgesandte) nennen konnte. Mit dem genuin lukanischen Apostelbegriff, wie er in 1,21f. dargelegt wird, hat der Apostolat des Paulus nichts $\mathrm{zu}$ tun. Eben dies demonstriert Lukas in V.4. 14 gegenüber den Irrlehrern, die Paulus für den Apostel schlechthin ansahen". 
It seems that Mark considered it necessary to distinguish between the sending of "the Twelve" (Mk 6:7) and the successful return of "apostles" (Mk 6:3). The designation "apostles" is a Markan addition. It does not occur in the "mission discourse" found in the Q collections (see Jacobson 1992:138-139). Matthew combined the concept "disciple" with "the Twelve" (Mt 10:1; 11:1), but did not report the successful completion of the mission, as did Mark and Luke (see Van Aarde 1994:103). Instead, Matthew considered it necessary to give the "twelve disciples" an own identity over against the "disciples" of John the Baptist (Mt 11:2ff). This episode appears in Luke before the commencement of the mission.

Luke (10:1) emphasized that the "itinerants" were other persons than "the Twelve". In Matthew's "mission discourse" the list of the names of "the Twelve" appears at the beginning of the mission (Mt 10:2-4), described as a mission to the "lost sheep of the house of Israel" (Mt 10:6). Jesus' appointment of "the Twelve" and the presentation of a list of their names coincide in Mark's gospel (Mk 3:16-19) and are reported to have happened prior to the mission (Mk 6:7ff). In Luke (6:14-16) the list of twelve names appears before Jesus reportedly presented a Sermon on the Plain (Lk 6:2049) and before he sent others on a mission beyond the boundaries of the homeland of the Israelites (Lk 10:1ff). As we have said, Matthew mentioned the list at the beginning of the mission discourse (Mt 10:2) and the mission is reported to have happened after the Sermon on the Mount (Mt 5-7). Mark's reference that "the Twelve" were sent out "two by two" (Mk 6:7) made that Matthew "arranged the twelve names in six pairs" (Harrington 1991:137). Luke saw the mission of the "seventy"//seventy two" as an itinerary of pairs. Luke knew that the "intinerants" were not "the Twelve".

Paul explicitly referred only to Peter as an apostle (see Gl $1: 17-19 ; 2: 8$ ). Allusions in this regard to John (the son of Zebedee) and James (the brother of Jesus) seem to be ambiguous. Within the context of Galatians 2:1-10 the reference to James and John (vs 9) in juxtaposition to Cephas (explicitly called an "apostle" in vs 8) could indicate that they were included among the apostles. Also Galatians 1:19 may be read as "I did not see any other of the apostles except ( $\varepsilon i \mu \eta \dot{)}$ James" or as "I did not see any other of the apostles,

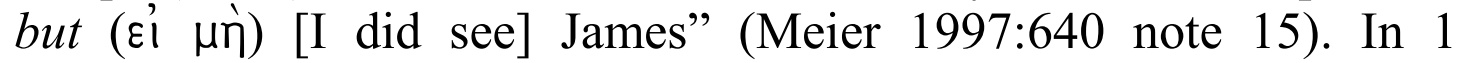
Corinthians 15:9 Paul saw himself as "the last of the apostles". 
Because of this reference and also his articulation "all the apostles" as an expansion of the "the Twelve", it seems that Paul did not fully equate the "apostles" with "the Twelve". He did, however, regard "the Twelve" as among the "apostles". The context of Galatians 1 and 2 also does not clearly indicate whether Paul regarded only Peter, James (the brother of Jesus) and John (the son of Zebedee) or the entire group of "the Twelve" as the "pillars" (G1 2:9).

\section{FINDINGS}

In the New Testament as a whole references to the "the Twelve" are relatively scarce ${ }^{18}$. According to Meier (1997:671) the "reasons for the swift disappearance or total absence of the Twelve from most of the NT are unclear". He suggests that after the death of some members (such as the martyred James, the son of Zebedee) during the first decade after Jesus' crucifixion, "it made little sense to continue to speak of the Twelve in regard to the present situation of the church ...". Or it could be that "the power of the Twelve as a group was eclipsed by the ascendancy of individual leaders like Peter or James [the brother of Jesus?], or some other members of the Twelve imitated Peter in undertaking a mission to Diaspora Jews in the East or the West - thus leaving no visible group of twelve leaders 'on the scene' in Palestine"19.

Schmithals (1972:398-401) notes in his article "Die Markusschluß: Die Verklärungsgeschichte und die Aussendung der

18 Meier (1997:670) puts it as follows: "(T)he Twelve are mentioned in the Four Gospels, in the pre-Pauline formula in 1 Cor 15:5, and in the early chapters of the Acts of the Apostles (the group called the Twelve is never mentioned after Acts 6:2, while even references to 'the apostles' diminish notably after chap. 8, disappearing entirely after 16:4). This exhausts all purportedly historical reports of the Twelve in the NT. They are mentioned again only fleetingly in Rev.21;14, an apocalyptic vision of the heavenly Jerusalem at the end of time ("the twelve apostles of the Lamb)".

19 Meier (1997:671-672 note 83) summarizes Schmithals' (1969:69-70) viewpoint as follows: "(1) a life of Jesus without the Twelve, (2) the sudden creation of the Twelve after Easter as a result of a resurrection appearance, (3) the conferral of such an important and lofty status on the Twelve in the early church that the group was retrojected into various streams of NT tradition (Mark, Q, L, and John), (4) the disintegration of the Twelve quite early as the apostasy of Judas and not later that the martyrdom of James the son of Zebedee, and consequently (5) the almost total absence of the Twelve from the rest of the traditions and writings of the first-century church". 
Zwölf" that Mark was the first to retroject "the Twelve" into the public ministry. Schmithals, like many other historical critical exegetes (cf Funk 1998:106), sees Mark's transfiguration story (Mk 9:2-8) as a re-worked edition of a story of an appearance of the risen Jesus. These apearances tradition links up with Mark's understanding of Jesus as Son of God within a Greco-Roman environment and the apostolate of the church outside the boundaries of Judean particularity. Mark was the first to "free" the Jerusalem group from their particularistic attitude by transforming their selfdesignation (as though they are "the Twelve") into "apostles". By doing so, Mark in fact criticized the leaders of the Jesus group in Jerusalem (cf Conzelmann 1988:341-342).

Although Meier (1997:637-638) sees this view as "complicated" and a "convoluted hypothesis", I concur fully with Schmithals in this regard. According to Meier, Schmithals sketches the origin and disappearance of the idea of "the Twelve" as a "meteoric rise" followed by a "meteoric fall". It "strains credulity and in the end is totally unnecessary" (Meier 1997:672 note 83). Meier utilizes both the "criteria" of "multiple independent attestation" and "embarrassment" to argue that the "circle of the Twelve did (probably) exist during Jesus' public ministry." However, exactly in light of multiple independent attestation the possibility Jesus created the idea of "the Twelve" is highly improbable. Both concepts "the Twelve" and "apostles" are lacking in the earliest Jesus traditions (e g, miracles, chreias, apothegms, and controversy reports). The idea of "the Twelve" should rather be seen as going back to the earliest Jesus group in Jerusalem (cf Conzelmann 1988:341-342).

The primary evidence for this statement, from a tradition critical perspective, is that both Paul and Mark related their knowledge of the idea of "the Twelve" to their receipt of the kerygmatic tradition (gospel about the salvation through the death and resurrection of Jesus). This tradition is said to have been taken over from the leaders in the Jerusalem group who regarded themselves as "the Twelve". From the ten (or eleven) times that Mark mentioned "the Twelve" two "at least ... seem firmly embedded in the pre-Markan tradition"20 (Meier 1997:644; cf

20 The list of names in Mk 3:16-19 and the reference to Judas as "one of the Twelve" in Mk 14:43. 
Schmahl 1972:203-213; Trilling1977:204-206; Kertelge 1969:193206). The list of the names of "the Twelve" appears in Matthew at the beginning of the mission discourse. This is specifically important because it demonstrates that the Sitz im Leben of the sending of "twelve apostles" on a mission does not go back to he historical Jesus ${ }^{21}$.

Some scholars (Klein 1961; Schmithals [1961] 1969) do not think that "the Twelve" count as "apostles" in the earliest Christianity and others (such as Roloff 1965:57-60) believe they were. Meier's (1997:64) opinion is that it was "in the early church that 'apostle' was first used as a set designation for a specific group - though different authors used the designation in different ways".

Which of these opinions is correct can only be ascertained if expressions such as the "earliest days of the church" and "early church" are clarified. One should keep in mind that, since its earliest days, the "church" was a diverse phenomenon. Furthermore, the concept "church" cannot be applied to all the Jesus movements that existed during the "earliest days" after Jesus' death ${ }^{22}$. Considering historical critically the development of the disciple tradition, it has become clear that the post-Easter resurrection belief in particular influenced this tradition. This influence pertains specifically to the convictions held in Jerusalem by influential male followers of Jesus.

21 In this regard, Kloppenborg's (1987:72) remark about Matthew's conflation of Q with Mark is relevant: "That Matthew both conflates Q with with Mark and displaces Marcan stories is a matter of empirical fact. When we encounter a Q pericope which is conflated with a Marcan story [e g, the sending (Q) of the Twelve, designated as apostles (Mark) and, therefore, referred to as twelve apostles (Matthew)] we may assume that the setting is secondary. Similarly, when a cluster of Q sayings [e g, those relating to the so-called 'mission discourse'] is placed in such a way as to fulfil a specific function in respect to the Marcan framework or Marcan materials (i.e., a function it could not originally have had in Q [e g, Mark's presentation of the mission discourse in terms of his 'sandwich-style']), then its position is certainly secondary" (emphasis by Kloppenborg, but my additions).

22 Form critical exegetes have broadly distinguished three Sitze im Leben: that of the pre-Easter Jesus (the historical Jesus), the early Jesus movements (which transmitted the Jesus traditions orally and in written form) and the writing of individual "Christian" documents (based upon the transmitted oral and written traditions in combination with authorial Sondergut). 
They regarded themselves as "apostles" (i e, legitimized "agents" of the vision of Jesus) and as the most important "prophets" (i e, "the Twelve" analogous to the twelve patriarchs) of the "new Israel". The Jerusalem group seemingly understood the notion of "the Twelve" as exchangeable for "all of Israel", represented by "all the apostles". In Paul's version of the traditional formula it is clear that he differed from this juxtaposition ${ }^{23}$. For Paul the concept "apostles" is an expansion of "the Twelve" in Jerusalem.

\section{Consulted literature}

Best, E [1983] 1985. Mark: The gospel as story. Reprinted. Edinburgh: T \& T Clark (Studies of the New Testament and its World).

Brox, N 1991. Der Hirt des Hermas. Göttingen:Vandenhoeck \& Ruprecht. (Ergänzungsreihe zum kritisch-exegetischen Kommentar über das Neue Testament 7).

Bultmann, R [1928] 1969. The significance of the historical Jesus for the theology of Paul, in Faith and understanding, Volume I, 220-246. Edited with an introduction by R W Funk and translated by L P Smith. London: SCM.

-, [1960] 1965. Das Verhältnis der urchristlichen Christusbotschaft zum historischen Jesus. 4.Auflage. Heidelberg: Carl Winter, Universitätsverlag. (SHAW 3).

Cameron, R 1982. The other gospels: Non-canonical gospel texts. Philadelphia, PA: Westminster.

Conzelmann, H [1959] 973. Jesus. The classic article from $\mathrm{RGG}^{3}$ expanded and updated, translated by I.\& F. McLuskey with J M Robinson. San Francisco: Harper \& Row.

-, 1988. History of early Christianity, in Conzelmann, H \& Lindemann A, Interpreting the New Testament: An introduction to the principles and methods of NT exegesis, 336-353, tr by S S Schatzmann from the $8^{\text {th }}$ rev German edition. Peabody, MA: Hendrickson.

Crossan, J D [1985] 1992. Four other gospels: Shadows on the contours of canon. Sonoma:Polebridge. Originally published in 1985 by Seabury Books.

-, 1991a. The historical Jesus: The life of a Mediterranean Jewish peasant. San Francisco:Harper.

-, 1991b. The life of a Mediterranean Jewish peasant. The Christian Century December 18-25, 1991:194-1204.

23 Apart from himself, Paul named Junia, Andronicus, Cephas, and probably James, and Silvanus as apostles (cf Gaston 1984:67 note 36). 
-, 1998. The Gospel of Peter and the canonical gospels. Forum (New Series) $1(1), 7-52$.

Davies, W D \& Allison, D C [1997] 2004. The Gospel according to Saint Matthew, Volume III. London:T \& T Clark/A Continuum Imprint. ICC.

Dewey A J 1998. The passion narrative of the Gospel of Peter. Forum (New Series)1(1), 53-70.

Draper, J 1985. The Jesus tradition in the Didache, in Wenham, D (ed), The Jesus tradition outside the gospels, 269-287. Sheffield: JSOT Press. (Gospel Perspectives 2.)

Fortna, R T 1988. The Fourth Gospel and its predecessor: From narrative source to present gospel. Philadelphia:Fortress.

Gaston, L 1984. Paul and Jerusalem, in Richardson, P \& Hurd, J C, From Jesus to Paul: Studies in honour of Francis Wright Beare, 62-72. Waterloo, Ontario: Wilfrid Laurier University Press.

Geyser, A S 1945. Die vroegste heidenberig oor Christus en die Christene. HTS 2(1), 5-16.

-, 1986. Israel in the Fourth Gospel. Neotestamentica 2, 13-20.

Gnilka, J 1993. Jesus von Nazaret: Botschaft und Geschichte. Freiburg: Herder.

Harrington, D J 1991. The Gospel of Matthew. Collegeville, MN: Liturgical Press. (Sacra Pagina 1).

Hübner, H 1981. Der "Messias Israels" und der Christus des NT. KuD 27, 217 240.

Jacobson, A D 1992. The first gospel: An introduction to Q. Sonoma, CA: Polebridge.

Käsemann, E 1960. Die Anfänge christlicher Theologie. ZThK 57, 162-185.

Kertelge, K 1969. Die Funktion der "Zwölf” im Markusevangelium. Trierer Theologische Zeitschrift 78, 193-206.

Klein, G 1961. Die zwölf Apostel: Ursprung und Gehalt einer Idee. Göttingen: Vandenhoeck \& Ruprecht (FRLANT 77).

Kloppenborg, J S 1987. The formation of Q: Trajectories in ancient wisdom collections. Philadelphia, PA: Fortress (Studies in Antiquity and Christianity).

Koester, H 1980. Gnostic writings as witnesses for the development of the sayings traditions, in Koester, H (ed), The rediscovery of Gnosticism, Vol 1. Proceedings of the International Conference on Gnosticism at Yale. New Haven, CT, March 28-31, 1978, 238-261. Leiden: Brill, The School of Valentinus. Studies in the History of Religions: Supplements to Numen 41).

-, [1980] 1987. Introduction to the New Testament, Vol 2. Philadelphia:Fortress (Hermeneia: Foundations and Facets).

-, 1990. Ancient Christian gospels: Their history and development. Philadelphia: Trinity Press International. 
Koester, H \& Patterson, S J 1991. Secret Mark. The Fourth R 4(3), 14-16.

Layton, B 1968. The sources, date and transmission of Didache 1.3b-2.1. HTR 61, 343-383.

Lüdemann, G [1994] 1994. The resurrection of Jesus: History, experience, theology, translated by J Bowden. Minneapolis, MN: Fortress.

Martyn, J L 1997. Galatians. New York: Doubleday. (Anchor Bible 33A).

Meier, J P 1997. The circle of the Twelve: Did it exist during Jesus' public ministry? JBL 116(4), 635-672.

Meye, R P 1968. Jesus and the Twelve. Grand Rapids: Eerdmans.

Miller, M P 1995. "Beginning from Jerusalem ...": Re-examining canon and consensus. Journal of Higher Criticism 2(1), 3-30.

Miller, R J (ed) 1992. The complete gospels: Annotated Scholars Version. Sonoma:Polebridge.

Osiek, C 1997. The Shepherd of Hermas in context. Acta Patristica et Byzantina 8, 115-134.

Pagels, E \& Koester, H 1978. Report on the Dialogue of the Savior, in Wilson, McL R (ed), Nag Hammadi and Gnosis: Papers read at the First International Congress on Coptology (Cairo, December 1976), 66-74. Leiden: Brill (NHS 14).

Patterson, S J 1993a. The Gospel of Thomas and Jesus. Sonoma, CA: Polebridge (Foundations \& Facets Reference Series).

-, 1993b. The Gospel of Thomas and Jesus. The Fourth R 6(3), 8-13.

Pilch, J J 1997. Are there Jews and Christians in the Bible? HTS 53(1\&2), 119125.

Rhoads, D \& Michie, D 1982. Mark as story: An introduction to the narrative of a gospel. Foreword by R Price. Philadelphia, PA: Fortress.

Riley, G J 1994. The Gospel of Thomas in recent scholarship. Currents in Research: Biblical Studies 2, 227-252.

Roloff, J 1965. Apostolat - Verkündigung - Kirche. Gütersloh: Gerd Mohn.

Schille, G 1994. Die Jesusbewegung und die Entstehung der Kirche. ThLZ 119, 100-112.

Schillebeeckx, E 1974. Jezus: Het verhaal van een levende. Tweede vermeerderde druk. Bloemendaal: H Nielsen.

Schrage, W 1963. "Ekklesia" und "Synagoge": Zum Ursprung des urchristlichen Kirchenbegriffs. ZThK 60, 178-202.

Schüssler Fiorenza, E 1994. Jesus-Miriam's child, Sophia's prophet: Critical issues in feminist Christology. New York: Continuum.

Schmahl, G 1972. Die Berufung der Zwölf im Markusevangelium. Trierer Theologische Zeitschrift 81, 203-213. 
Schmithals, W [1961]1969. The office of apostle in the early church. Nashville, TN: Abingdon (Originally published as Das kirchliche Apostelampt, Göttingen: Vandenhoeck \& Ruprecht).

-, 1982. Die Apostelgeschichte des Lukas. Zürich: Theologischer Verlag (Zürcher Bibelkommentare).

-, 1986. Das Evangelium nach Markus: Kapitel 9,2-16,20. 2. berichtigte und ergänzte Auflage. Gütersloh: Güterloher Verlaghaus (Ökumenischen Taschenbuchkommentar zun Neuen Testament 2/2).

Smith, D E 2000. Was there a Jerusalem church? Christian origins in Jerusalem according to Acts and Paul. Forum (New Series) 3(1), 57-74.

Smith, M 1973. The Secret Gospel: The discovery and interpretation of the Secret Gospel according to Mark. New York: Harper \& Row.

Theissen, G \& Winter, D 1997. Die Kriterienfrage in der Jesusforschung: Von Differenzkriterium zum Plausibalitätskriterium. Göttingen: Vandenhoeck \& Ruprecht (Novum Testamentum et Orbis Antiquus).

Trilling, W 1977. Zur Entstehung der Zwölferkreises: Eine geschichtkritische Überlegung, in Schnackenburg, R, Ernst, J \& Wanke, J (Hrsg), Die Kirche des Anfangs: Heinz Schürmann Festschrift, 201-222. Leipzig: St. Benno.

-, 1978. Implizite Ekklesiologie: Ein Vorschlag zum Thema "Jesus und die Kirche", in Trilling, W, Die Botschaft Jesu: Exegetische Orientierung, 5772. Freiburg: Herder.

Van Aarde, A G 1985. Die outeurskapsvraag van die Johannesevangelie met die oog op interpretasie of resepsie. Skrif en Kerk 6, 45-62.

-, 1994. God-with-us: The dominant perspective in Matthew's story, and other essays. Pretoria: Gutenberg Publishers (HTS Suppl 5).

-, 1999. The historicity of the circle of the Twelve: All roads lead to Jerusalem. HTS 55(2\&3), 795-826.

-, 2001. Matthew and apocalypticism as the "mother of Christian theology": Ernst Käsemann revisited. Paper presented at the Gospel of Matthew Seminar, Studiorum Novum Testamenti Societas, $56^{\text {th }}$ General Meeting, Faculté de théologie de l' Université de Montréal, Canada, 31 July-4 August 2001.

Vermes, G 1993. The religion of Jesus. Minneapolis, MN: Fortress.

Von Wahlde, U C 1989. The earliest version of John's gospel: Recovering the Gospel of Signs. Wilmington: Glazier. 